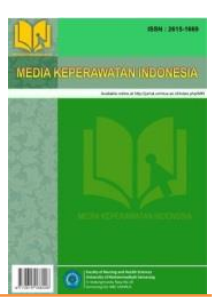

Research article

\title{
Prevention of Increasing Total Cholesterol Level Using Cowpea Yoghurt
}

\author{
Maulana Rahmat Hidayatullah
}

Program Studi DIII Keperawatan, Stikes Pamenang

\section{Article Info}

\section{Article History: \\ Accepted 28 February 2020}

Keywords:

Cowpea yogurt; Vigna

unguiculate; Total

cholesterol; Atherosclerosis
Abstract

Atherosclerosis is lipoprotein metabolism disorder which is marked by an increase of total cholesterol level in blood serum. Cowpea contains a lot of isoflavones that can inhibit the activity of the enzyme HMG-CoA reductase in the cholesterologenesis process. The aim of this study is to find out cowpea yogurt which can prevent the increasing total cholesterol level. This study used an experimental study with a post-test only control group design in 30 male rats. It was divided into 5 groups: Results showed that the total cholesterol level among the fifth group was a significant difference (KruskalWallis, $p=0,000$ ). The conclusion of this study is cowpea yogurt can prevent the increasing total cholesterol levels of Wistar rats induced by a high-fat diet.

\section{PENDAHULUAN}

Salah satu masalah kesehatan terbesar yang di alami di berbagai negara di dunia ini adalah Aterosklerosis (Furuncuoglu, Basar, Alıcl, \& Sengul, 2014; Soleha \& Maratu, 2012). Tingginya angka kejadian berbagai penyakit kardiovaskuler seperti stroke, penyakit jantung koroner, dan penyakit pembuluh darah perifer sangat erat hubungannya dengan kondisi aterosklerosis dalam tubuh (Chabib, 2017; Purnawarman \& Nurkhalis, 2014; Yani, 2015). Aterosklerosis terjadi karena adanya respon inflamasi kronik terhadap deposisi kolesterol pada dinding pembuluh darah arteri (Mukminah et al., 2016). Hasil akhir dari atherosklerosis adalah penyempitan dan pergeseran pembuluh darah akibat penumpukan plak lemak, kolesterol sisa metabolisme lemak, kalsium, dan jaringan fibrosa yang secara progresif menyebabkan iskemia miokardium, akibat penyempitan lumen koronaria dan volume darah yang menurun (Cheng et al., 2011; Tsalissavrina, Wahono, \& Handayani, 2013). Kolesterol total adalah salah satu variabel lipid yang berpengaruh besar terhadap kadar lipid plasma. Berdasarkan teori keperawatan Virginia Handerson diungkapkan bahwa teori dasar kebutuhan manusia salah satunya adalah kebutuhan nutrisi. Tingginya asupan diet tinggi lemak dapat mengakibatkan ketidakseimbangan nutrisi dalam tubuh yang menimbulkan gangguan kesehatan manusia karena tidak terpenuhi kebutuhan dasar keseimbangan nutrisinya (Cheng et al., 2011; Tsalissavrina, Wahono, \& Handayani, 2013).

Kadar kolesterol total dikatakan tinggi jika melampaui 200 mg/dl. Kenaikan serum ini 
menjadi salah satu prediktor terjadinya dislipidemia dan meningkatkan pula risiko penyakit jantung koroner (Cheng et al., 2011). Penelitian sebelumnya menunjukkan bahwa setiap penurunan kolesterol total $1 \%$ dapat menurunkan resiko penyakit kardiovaskular sebesar 2\% (Boudi \& Ahsan H, 2014). Sehingga pemantauan dan penurunan kadar kolesterol total adalah penting untuk dilakukan. Pengaturan pola makan dan modifikasi diet merupakan salah satu cara membantu menekan peningkatan kadar lipid darah. Pengaturan pola makan yang dianjurkan adalah dengan membatasi konsumsi makanan yang mengandung kolesterol dan lemak jenuh (Mukminah et al., 2016; Schwingshackl \& Hoffmann, 2013). Selain itu, mengonsumsi jenis makanan yang memiliki manfaat untuk menurunkan kadar kolesterol juga diperlukan. Salah satu jenis bahan makanan tersebut adalah bahan makanan dengan kandungan isoflavon (Mukminah et al., 2016).

Selama ini, dislipidemia dikendalikan dengan terapi obat. Namun terapi obat tersebut ternyata memiliki efek samping berupa gangguan gastrointestinal dan dapat menghambat koenzim Q10 yang berfungsi untuk mencegah oksidasi LDL (Marques et al., 2015). Penggunaan statin jangka panjang juga dapat menyebabkan miopati dan toksisitas hati (Ahmad, 2014; Huddy, Dhesi, \& Thompson, 2013). Di sisi lain terapi diet dengan cara memodifikasi pola diet menjadi diet rendah lemak jenuh dan kolesterol dapat menurunkan kadar kolesterol total secara lebih murah dan aman untuk dilakukan, namun demikian banyak orang yang mengalami kegagalan dalam menjaga pola diet agar tetap seimbang sehingga perlu adanya inovasi baru tentang solusi terhadap pencegahan peningkatan kolesterol total darah. Hal ini dapat dicapai dengan cara mengonsumsi bahan makanan yang memiliki kandungan tinggi isoflavon yang efektif mengurangi kecepatan reaksi pembentukan kolesterol di dalam hati (Marques et al., 2015).
Aterosklerosis sebenarnya bersifat reversible, dapat menipis kembali apabila kadar kolesterol dalam darah berhasil dikontrol dengan baik terutama menurunkan kadar kolesterol total darah (Mukminah et al., 2016; Sanhia, Pangemanan, \& Engka, 2015). Pencegahan aterosklerosis dapat dilakukan dengan manajemen diet yang baik terutama makanan dengan kandungan isoflavon yang tinggi(Sari, Prihartini, \& Brantas, 2014). Kacang tunggak mengandung isoflavon yang termasuk golongan flavonoid (1,2diarilpropan. Penelitian terhadap senyawa ini menunjukkan bahwa isoflavon bereaksi menghambat akselerasi enzim 3-hidroxi 3metilglutarat Coa yang berperan sebagai enzim esterifikasi kolesterol dan solubelitas misel. Isoflavon menurunkan kecepatan enzim ini sebesar $89 \%$ dari 3kDa (Noviani, 2011; Soediono, 2014). Hasil akhir dari reaksi ini adalah menurunnya kadar kolesterol total sehingga dapat menurunkan resiko penyakit kardiovaskuler (Soediono, 2014). Pengolahan dengan cara fermentasi akan menghasilkan senyawa isoflavon bebas yang terbanyak. Sehingga kacang tunggak berpotensi dijadikan produk olahan fermentasi salah satunya yoghurt (Marques et al., 2015; Noviani, 2011).

Penelitian ini bertujuan untuk mengetahui apakah pemberian yoghurt kacang tunggak dengan kandungan isoflavon selama 8 minggu dapat mencegah peningkatan kadar kolesterol total pada tikus wistar yang diberi diet aterosklerosis.

\section{METODE}

Penelitian ini dilaksanakan di Laboratorium Farmakologi Universitas Brawijaya selama delapan minggu. Penelitian ini adalah penelitian eksperimental dengan rancangan Randomized Post Test Only Controled Group Design. Penelitian ini menggunakan lima kelompok yaitu kelompok kontrol negatif, kontrol positif, perlakuan 1 , perlakuan 2 , dan perlakuan 3 dengan metode randomisasi sederhana menggunakan 
Rancangan Acak Lengkap. Hal ini dikarenakan hewan coba ,tempat percobaan dan bahan penelitian lainnya bersifat homogen. Penelitian hanya dilakukan pada post test dengan membandingkan hasil observasi pada kelompok perlakuan dengan kelompok kontrol.

Populasi penelitian ini adalah tikus wistar jantan 30 ekor tikus yang dibagi dalam lima kelompok. Kriteria inklusi tikus jenis Rattus norvegicus strain wistar, berat badan tikus rerata 150-200 gram, umur 2-3 bulan, jenis kelamin jantan,warna bulu putih dan tikus bergerak aktif. Pemilihan tikus pada penelitian ini karena beberapa pertimbangan antara lain tikus termasuk jenis vertebrata yang mempunyai kesamaan filogenik dan respon biologi yang mendekati manusia, pemakan sembarang (omnivora), mudah diperoleh dan mudah diberikan perlakuan. Selain itu, tikus jantan yang dipilih karena tikus betina terdapat esterogen yang mempengaruhi metabolisme lemak dan kolesterol.

Variabel independen dari peneltian ini adalah yoghurt kacang tunggak (Vigna unguiculata) dan diet tinggi lemak sedangkan variable dependennya adalah kadar kolesterol kolesterol total tikus wistar. Tikus wistar pada kelompok kontrol negatif hanya diberi pakan standar selama 8 minggu, kelompok kontrol positif diberi diet tinggi lemak selama 8 minggu, kelompok perlakuan 1 diberi diet tinggi lemak + yoghurt kacang tunggak dosis isoflavon $1.6 \mathrm{mM} /$ rerata gram BB tikus/hari selama 8 minggu, kelompok perlakuan 2 diberi diet tinggi lemak + yoghurt kacang tunggak dosis isoflavon 2.4 $\mathrm{mM}$ / rerata gram BB tikus/hari selama 8 minggu dan kelompok perlakuan 3 diberi diet tinggi lemak + yoghurt kacang tunggak dosis isoflavon $3.2 \mathrm{mM} /$ rerata gram BB tikus/hari selama 8 minggu.

Pada hari ke-56 dilakukan terminasi tikus dan pemeriksaan kadar kolesterol total serum dalam darah. Darah diambil dengan spuit dari jantung bagian ventrikel kanan sebanyak $1 \mathrm{ml}$, kemudian dilakukan pengukuran secara enzimatis dan spektrofotometer. Kadar kolesterol total ditentukan dengan metode langsung (TC Direct). Pemeriksaan kadar kolesterol total dilakukan di Laboratorium Klinik Kawi 31 Malang.

Data hasil penelitian yaitu kadar kolesterol total, setelah diedit dan decoding, akan dientri ke dalam file computer. Setelah dilakukan cleaning, dilakukan analisis statistic dengan SPSS 18.00 for windows, dilanjutkan dengan analisis univariat dengan menghitung nilai mean dan standart deviasi terhadap kadar kolesterol total, serta disajikan dalam bentuk tabel dan grafik. Data diuji normalitasnya dengan menggunakan uji Shapiro wilk. Jika sebaran data normal dan homogeny, maka uji hipotesis menggunakan uji Oneway ANOVA. Karena sebaran data tidak normal, maka uji hipotesis menggunakan Kruskal-Wallis test.

\section{HASIL}

Dalam penelitian ini pengukuran kadar kolesterol total tikus dilakukan setelah semua kelompok mendapat perlakuan selama 8 minggu. Setelah mendapat perlakuan dalam kurun waktu tersebut tikus diterminasi dan darah tikus diambil dari bagian jantung. Darah tersebut kemudian disentrifugasi untuk memisahkan serum tikus yang selanjutnya dipakai untuk pengukuran kadar kolesterol total. Pengukuran kadar kolesterol total serum dilakukan dengan menggunakan metode CHOD-PAP, dengan spektrofotometri dan menunjukkan hasil sebagai berikut:

Berdasarkan Gambar 1 diketahui bahwa rerata kadar kolesterol total tikus tertinggi sebesar 91,17 mg/dl pada kelompok KP. Sedangkan rerata kadar kolesterol total terendah sebesar $61,17 \mathrm{mg} / \mathrm{dl}$ pada kelompok P3. Sedangkan rerata kelompok yang lain secara berturut-turut adalah P1 
sebesar 72,17 mg/dl, P2 sebesar 67,75 $\mathrm{mg} / \mathrm{dl}$, dan P3 sebesar 61,17 mg/dl.

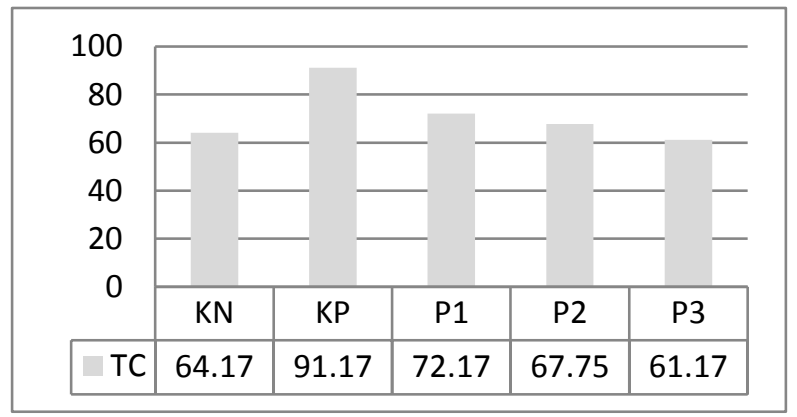

Gambar 1 Grafik Rerata Kadar Kolesterol Total Tikus (mg/dl)

Hasil Test Normality menunjukkan terhadap data rerata kolesterol tikus perlakuan diperoleh bahwa nilai kolesterol total kelompok tikus perlakuan 2 (kelompok diet tinggi lemak + yoghurt kacang tunggak dosis $2,4 \mathrm{mM} / \mathrm{g}$ BB) tidak dalam keadaan normal dengan nilai $p>0,05$ ( $p=0,041)$. Hal ini dapat dilihat pada table 1 tentang uji normalitas dan homogenitas kadar kolesterol total.

Selanjutnya untuk menguji hipotesis penelitian maka peneliti menggunakan alternative uji yaitu Kruskal-Wallis Test Berikut hasil uji statistika kolesterol total dapat dilihat pada tabel 2 dan tabel 3 .

Tabel 1

Perbedaan Kadar Kolesterol Total Tikus Wistar Ateroskleosis

\begin{tabular}{lccc}
\hline Indikator & df & $\mathbf{N}$ & $\mathbf{P}$ \\
\hline Kolesterol Total & 4 & 28 & $0,000^{*}$ \\
\hline
\end{tabular}

*Uji Kruskal-Wallis

Berdasarkan hasil uji tersebut terlihat bahwa besar sampel dalam penelitian ini adalah 28. Pada $P$ value tampak nilai 0,000 yang menunjukkan bahwa rerata kadar kolesterol total antar kelompok perlakuan dan kontrol adalah berbeda signifikan.

Setelah dilakukan uji kruskal wallis untuk mengetahui signifikansi hasil penelitian ini, selanjutnya adalah melakukan uji mann whitney untuk mengetahui kelompok mana saja yang berbeda signifikan. Uji ini mampu menunjukkan nilai signifikansi perbedaan antar kelompok.

Tabel 2

Perbedaan kadar Kolesterol Total Tikus Tikus Wistar Ateroskleosis

\begin{tabular}{lll}
\hline \multicolumn{2}{c}{ Indikator } & \multicolumn{1}{c}{ p } \\
\hline \multirow{3}{*}{ Negatif } & Positif & $0,004^{*}$ \\
\cline { 2 - 3 } & Perlakuan 1 & $0,005^{*}$ \\
\cline { 2 - 3 } & Perlakuan 2 & 0,131 \\
\cline { 2 - 3 } Positif & Perlakuan 3 & 0,198 \\
\cline { 2 - 3 } & Perlakuan 1 & $0,004^{*}$ \\
\hline \multirow{2}{*}{ Perlakuan 1 } & Perlakuan 2 & $0,010^{*}$ \\
\cline { 2 - 3 } & Perlakuan 3 & $0,004^{*}$ \\
\hline Perlakuan 2 & Perlakuan 2 & $0,049^{*}$ \\
\hline
\end{tabular}

* Uji Mann-whitney

Nilai signifikansi perbedaan yang tertinggi adalah antara kelompok control negatif dengan control positif, kelompok control positif dengan perlakuan 1, kelompok control positif dengan perlakuan 3 , dan kelompok perlakuan 1 dengan perlakuan 3 . Sedangkan untuk kelompok dengan nilai signifikansi perbedaan yang terendah adalah antara kelompok perlakuan 1 dengan perlakuan 2. Namun demikian dapat dilihat pula bahwa ada beberapa perbandingan kelompok yang tidak signifikan yaitu antara kelompok kontrol negatif dengan perlakuan $2 \mathrm{p}=0,131$ $(\mathrm{P}<0,05)$ dan kelompok kontrol negatif dengan perlakuan $3 \mathrm{p}=0,198(\mathrm{P}<0,05)$.

\section{PEMBAHASAN}

Rerata kadar kolesterol total pada kelompok kontrol positif yang lebih tinggi daripada kelompok kontrol negatif sejalan dengan hasil penelitian sebelumnya yang menunjukkan adanya perbedaan signifikan kadar kolesterol total tikus yang diberi diet aterosklerosis dengan kelompok kontrol. Kelompok yang diberikan diet aterosklerosis menunjukkan kadar kolesterol totalnya tinggi hingga lebih dari 200 mg/dl (Cheng et al., 2011; Furuncuoglu et al., 2014). Perbedaan yang signifikan antara dua kelompok ini memiliki arti 
bahwa diet tinggi lemak meningkatkan kadar kolesterol Total. Hal ini sesuai dengan penelitian yang serupa yang mengungkapkan bahwa kemungkinan dikarenakan terjadinya penurunan rerata kadar trigliserida tikus perlakuan berkaitan dengan adanya bahan isoflavon dalam kacang tunggak yang mampu menghambat aktivitas enzim 3-hydroxy 3-methylglutaryl CoA (HMG-CoA) yang berperan dalam penghambatan sintesis kolesterol serta enzim acyl-CoA: Cholesteryl aciltransferase. Enzim tersebut berperan dalam esterifikasi kolesterol, sebelum kolesterol diserap dan diubah menjadi kilomikron dalam usus. Selain itu isoflavon juga menurunkan kelarutan misel, absorbsi kolesterol dan asam empedu dalam usus (Marques et al., 2015), (Hah, As, Fma, Mf, \& Ash, 2016).

Peningkatan kadar kolesterol total pada tikus sampel terkait dengan komposisi diet tinggi lemak yang terdiri atas diet normal (PARS dan terigu) ditambah dengan kuning telur bebek, minyak babi, minyak kelapa dan asam kolat diberikan untuk menginduksi peningkatan kolesterol dalam darah. Minyak babi diberikan karena kandungan kolesterol yang lebih tinggi dibandingkan dengan minyak hewani lain dan minyak nabati. Kuning telur bebek dan minyak kelapa digunakan sebagai sumber kolesterol tambahan untuk meningkatkan kadar kolesterol pakan. Asam kolat diberikan karena jika tanpa asam kolat, maka pemberian diet tinggi lemak selama 8 minggu tidak akan meningkatkan kadar kolesterol total secara bermakna (Cheng et al., 2011).

Penggunaan komposisi diet tinggi lemak seperti yang telah diuraikan $\mathrm{di}$ atas menyebabkan kelompok tikus yang diberi diet tinggi lemak memiliki kadar kolesterol total lebih tinggi $(91,17 \mathrm{mg} / \mathrm{dl})$ bila dibandingkan dengan kelompok diet normal $(64,17 \mathrm{mg} / \mathrm{dl})$. Adapun kadar kolesterol total tikus dalam kondisi normal adalah < $74 \mathrm{mg} / \mathrm{dl}$ (Lintong, 2009). Perbedaan signifikan antara kelompok diet normal dan diet tinggi lemak dapat disimpulkan bahwa pemberian diet tinggi lemak yang dilakukan dalam penelitian ini dapat meningkatkan kadar kolesterol total tikus secara signifikan. Dengan demikian dapat dikatakan bahwa pemberian diet tinggi lemak dalam penelitian sudah mencapai kondisi hiperkolesterolemia.

Proses fermentasi yang menggunakan bakteri asam laktat juga mampu meningkatkan aktivitas antioksidan pada kacang tunggak. Pada penelitian yang lain yang juga menggunakan bakteri yoghurt menjelaskan bahwa proses fermentasi mengubah bentuk isoflavon glukosida menjadi isoflavon aglikon yaitu daidzein, genistein, glisitein, dan faktor II $(6,7,4$ trihidroksiisoflavon). Senyawa-senyawa turunan tersebut memiliki aktivitas antioksidan yang lebih tinggi dibandingkan dengan isoflavon glukosida (Furuncuoglu et al., 2014; Marques et al., 2015). Bakteri asam laktat selain menormalkan mikroflora usus juga meningkatkan bioavailabilitas isoflavon dalam tubuh sehingga isoflavon dapat mengoptimalkan perannya dalam menurunkan kadar kolesterol total dan trigliserida serum (Soleha \& Maratu, 2012). Pada penelitian sebelumnya pada tahun 2015 oleh marquez et al memaparakan bahwa antioksidan yang terkandung dalam kacang tunggak mampu menurunkan absorpsi kolesterol dan trigliserida oleh usus baik dari diet sehari-hari maupun yang diproduksi dari hati dan kemungkinan juga mengurangi reabsorpsi asam empedu yang dapat menyebabkan peningkatan sekresi sterol netral dan asam empedu dalam feses karena asam empedu berfungsi mengikat kolesterol dan trigliserida. Adanya mekanisme tersebut mengakibatkan pembentukan kilomikron dan VLDL juga terhambat sehingga kadar kolesterol dan trigliserida turun (Marques et al., 2015).

Penentuan dosis pada penelitian ini merujuk pada penelitian yang menggunakan dosis yoghurt kacang tunggak ke-3 (3,2 mM/g BB) untuk mengetahui pengaruh pemberian yoghurt kacang tunggak susu fermentasi terhadap 
kadar kolesterol total pada manusia (Marques et al., 2015). Pengonversian dosis yang sama pada penelitian tersebut untuk menurunkan kadar kolesterol total pada penelitian ini ternyata berhasil. Dari ketiga dosis yoghurt kacang tunggak pada penelitian ini pada semua perlakuan (dosis isoflavon $1,6 \mathrm{mM} / \mathrm{g} \mathrm{BB}, 2,4 \mathrm{mM} / \mathrm{g} \mathrm{BB}$, dan $3,2 \mathrm{mM} / \mathrm{g} \mathrm{BB}$ ) dapat menurunkan kadar kolesterol total sampel secara signifikan. Sebagai tindak lanjut, perlu dilakukan penelitian lebih lanjut untuk mengetahui rentang dosis yoghurt kacang tunggak yang memberikan efek optimal dalam menurunkan kadar kolesterol total tanpa menimbulkan efek toksik (Cheng et al., 2011; Yani, 2015).

\section{SIMPULAN}

Yoghurt kacang tunggak dapat mencegah peningkatan kadar kolesterol total. Perlu dilakukan penelitian serupa dengan jangka waktu lebih lama. Perlu dilakukan pula pengujian kadar isoflavon dan kemungkinan zat aktif lain yang terkandungan di dalam kacang tunggak.

\section{UCAPAN TERIMAKASIH}

Ucapan terimakasih kami sampaikan kepada semua pihak yang telah mendukung pelaksanaan penelitian ini.

\section{REFERENSI}

Ahmad, Z. (2014). Statin intolerance [JOUR]. The American Journal of Cardiology, 113(10), 17651771.

https://doi.org/10.1016/j.amjcard.2014.02.0 33

Boudi, B., \& Ahsan H, C. (2014). Noncoronary Atherosclerosis Overview of Atherosclerosis. Medscape, 1-14.

Chabib, M. (2017). Persepsi perempuan tentang penyakit jantung koroner di Puskesmas Jenangan, Kecamatan Jenangan Kabupaten Ponorogo (DISS). Universitas Muhammadiyah Ponorogo.

Cheng, T.-J., Chuu, J.-J., Chang, C.-Y., Tsai, W.-C., Chen, K.-J., \& Guo, H.-R. (2011). Atherosclerosis induced by arsenic in drinking water in rats through altering lipid metabolism [JOUR ]. Toxicology and Applied Pharmacology, Vol. 256, pp. 146-153. https://doi.org/10.1016/j.taap.2011.08.001

Furuncuoglu, Y., Basar, M., Alıcl, S., \& Sengul, C. (2014). Effects of a Stanol-Enriched Yogurt on Plasma Cholesterol Levels. Stenolden Zengileștirilmiş Yoğurtların Plazma Kolesterol Düzeylerine Etkisi.

Hah, S. A., As, S., Fma, A., Mf, R., \& Ash, G. (2016). Growth, yield and fatty acids response of oenothera biennis to water stress and potassium fertilizer application. International Journal of Pharmacy and Pharmaceutical Sciences; Vol 8, Issue 4, 2016.

Huddy, K., Dhesi, P., \& Thompson, P. D. (2013). Do the Frequencies of Adverse Events Increase, Decrease, or Stay the Same with Long-Term Use of Statins? [JOUR]. Current Atherosclerosis Reports, 15(2), 1-5. https://doi.org/10.1007/s11883-012-0301-9

Lintong, P. M. (2009). Perkembangan Konsep Patogenesis Aterosklerosis. Biomedik.

Marques, M. R., Soares Freitas, R. A. M., Corrêa Carlos, A. C., Siguemoto, É. S., Fontanari, G. G., \& Arêas, J. A. G. (2015). Peptides from cowpea present antioxidant activity, inhibit cholesterol synthesis and its solubilisation into micelles. Food Chemistry, 168, 288-293. https://doi.org/10.1016/j.foodchem.2014.07. 049

Mukminah, C., Wagustina, S., Gizi, J., Kesehatan Kemenkes Aceh, P., Soekarno Hatta, J., Terpadu Poltekkes, K., ... Total, K. (2016). Hubungan Kebiasaan Konsumsi Makanan Tinggi Lemak Jenuh Dengan Kadar Kolesterol Total Penderita Penyakit Jantung Koroner Rawat Jalan Di Blud Rsud Meuraxa Banda Aceh. AcTion Journal.

Nicholls, S. J., Tuzcu, E. M., Sipahi, I., \& Grasso, A. W. (2007). Statins, High-Density Lipoprotein Cholesterol, and Regression of Coronary Atherosclerosis [JOUR]. JAMA, Vol. 297, p. 499. Chicago : American Medical Association .

Noviani, R. W. (2011). Upaya Induksi Pembungaan Kacang Tunggak (Vigna unguiculata L., Walp) di Luar Musim dengan Berbagai Kerapatan Tumpangsari Jagung (Zea mays). Journal of Chemical Information and Modeling. https://doi.org/10.1017/СВ0978110741532 4.004

Purnawarman, A., \& Nurkhalis, N. (2014). Pengaruh 
Latihan Fisik Terhadap Fungsi Endotel [JOUR]. Jurnal Kedokteran Syiah Kuala, 14(2), 109-118.

Sanhia, A. M., Pangemanan, D., \& Engka, J. N. (2015). Gambaran Kadar Kolesterol Low Density Lipoprotein. E-Biomedik(EBm).

Sari, Y. D., Prihartini, S., \& Brantas, K. (2014). Asupan serat makanan dan kadar kolesterol-LDL... (Sari YD; dkk). Penelitian Gizi Dan Makanan.

Schwingshackl, L., \& Hoffmann, G. (2013). Comparison of effects of long-term low-fat vs high-fat diets on blood lipid levels in overweight or obese patients: a systematic review and meta-analysis [JOUR]. Journal of the Academy of Nutrition and Dietetics, 113(12), 1640-1661.

https://doi.org/10.1016/j.jand.2013.07.010

Soediono, B. (2014). Induksi Pembungaan Kacang Tunggak (Vigna unguiculata [L.] Walp) di Luar Musim dengan Penyesuaian Panjang Hari dan Stres Air. Journal of Chemical Information and Modeling. https://doi.org/10.1017/CB0978110741532 4.004

Soleha, \& Maratu. (2012). Kadar Kolesterol Tinggi Dan Faktor-Faktor Yang Berpengaruh Terhadap Kadar Kolesterol Darah. Jurnal Biotek Medisiana Indonesia.

Tsalissavrina, I., Wahono, D., \& Handayani, D. (2013). Pengaruh pemberian diet tinggi karbohidrat dibandingkan diet tinggi lemak terhadap kadar trigliserida dan HDL darah pada Rattus novergicus galur wistar [JOUR]. Jurnal Kedokteran Brawijaya, 22(2), 80-89.

Yani, M. (2015). Mengendalikan Kadar Kolesterol Pada Hiperkolesterolemia. Olahraga Prestasi. https://doi.org/10.1017/CB0978110741532 4.004 